\title{
Microleakage of Nanofilled Composite Resin Restorative Material
}

\author{
Ibrahim M. Hamouda ${ }^{1 *}$, Hagag Abd Elkader ${ }^{1}$, Manal F. Badawi ${ }^{1}$ \\ Dental Biomaterials Department, Faculty of Dentistry, Mansoura University, Mansoura, Egypt. \\ Email: *imh100@hotmail.com \\ Received November $11^{\text {th }}, 2010$; revised March $30^{\text {th }} 2011$; accepted May $28^{\text {th }}, 2011$.
}

\begin{abstract}
The role of nanofillers in reducing the microleakage of dental composite resins has not been previously investigated. So this study was designed to evaluate microleakage of nanofilled composite resin in comparison to the conventional hybrid composite. Twenty extracted sound molars were selected. Class II cavities were prepared. All cavities were etched (enamel and dentin) with $37 \%$ phosphoric acid. Dentin bonding agents were applied to etched tooth surfaces and restored with nanofilled and hybrid composite restorative materials. The restored teeth were thermocycled. Specimens were immersed in $2 \%$ methylene blue dye, sectioned along the mesio-distal direction; dye penetration of occlusal and gingival margins of each section was evaluated using a stereo-microscope. No significant difference was found between the microleakage of nanofilled and hybrid composite restorations at occlusal/enamel and at gingival/dentin margins. Also, there were no significant differences for nanofilled composite restorations at occlusal/enamel margins and gingi$v a l / d e n t i n$ margins. On the other hand, there were a significant differences for hybrid composite restorations at occlusal/enamel margins and gingival/dentin margins.
\end{abstract}

Keywords: Microleakage, Nanofilled Composite Resin, Hybrid Composite Resin

\section{Introduction}

Resin composites are increasingly used for restorative purposes because of good esthetic and the capability of establishing a bond to enamel and dentin [1]. However, like all dental materials, composites have their own limitations, such as the gap formation caused by polymerization contraction during setting, leading to marginal discoloration and leakage [2]. Improvements of mechanical properties of the composite have permitted its use in posterior teeth with greater reliability than was the case some years ago. This improvement included; development of smaller particle sizes of filler, better bonding systems, curing refinements and sealing systems [3].

Composite resin materials have progressed from macrofills to microfills and from hybrids to microhybrids, and new materials such as packable and nanofilled composites have been introduced to the dental market $[4,5]$. Each type of composite resin has certain advantages and limitations. The universal hybrid composites provide the best general blend of good material properties and clinical performance for routine anterior and posterior restorations [6]. A new brand of composite resins called nanofilled composites has been introduced to the dental mar- ket, which has been produced with nanofiller technology and formulated with nanomer and nanocluster filler particles. Nanomers are discrete nanoagglomerated particles of $20-75 \mathrm{~nm}$ in size, and nanoclusters are loosely bound agglomerates of nano-sized particles. The combination of nanomer-sized particles and nanocluster formulations reduces the interstitial spacing of the filler particles and, therefore, provides increased filler loading, better physical properties, and improved polish retention [3].

This investigation was designed to evaluate enamel and dentin microleakage of a nanofilled composite resin in comparison with conventional hybrid composite restorative materials.

\section{Materials and Methods}

The materials used in this study are presented in Table 1. A total of 20 specimens were prepared from both nanofilled and conventional hybrid composite resins. Specimens were cured with a light curing device (Chromalux E, Germany) according to the manufacturer's instructions.

Twenty freshly extracted sound (non-carious and nonrestored) mandibular human molars were selected and 
Table 1. Materials used in this study.

\begin{tabular}{|c|c|c|c|c|}
\hline Materials & Type & Composition & Batch/lot No. & Manufacturer \\
\hline Filtek $^{\mathrm{TM}}$ Supreme & $\begin{array}{l}\text { Light curing } \\
\text { nanofilled } \\
\text { Composite Resin }\end{array}$ & $\begin{array}{l}\text { Monomer matrix contains Bis-GMA, urethane } \\
\text { dimethacrylate, triethylene glycol dimethacrylate and } \\
\text { bis-EMA resin. Inorganic filler particles are a } \\
\text { combination of aggregated zirconia/silica cluster and } \\
\text { a non-agglomerated/non- aggregated silica filler. }\end{array}$ & $3910 \mathrm{~A} 3.5 \mathrm{~B}$ & $\begin{array}{l}\text { 3M ESPE Dental Products } \\
\text { St. Paul, MN } 55144\end{array}$ \\
\hline Prime-Dent ${ }^{\circledR}$ & $\begin{array}{l}\text { Visible light } \\
\text { cured hybrid } \\
\text { composite resin }\end{array}$ & $\begin{array}{l}\text { It is based on BIS-GMA resin and inorganic filler } \\
\text { particles with average diameter of } 1.40 \text { microns }\end{array}$ & MB010 & $\begin{array}{l}\text { Prime Dental Manufacturing } \\
\text { INC. } 3735 \text { W. Belmont Ave. } \\
\text { Chicago, IL. } 60618\end{array}$ \\
\hline $\begin{array}{l}\text { Aper }{ }^{\mathrm{TM}} \text { Single } \\
\text { Bond2 Adhesive }\end{array}$ & $\begin{array}{l}\text { Light curing } \\
\text { Bonding agent }\end{array}$ & Adhesive containing $10 \%, 5 \mathrm{~nm}$ colloidal filler & 4BK51202 & $\begin{array}{c}\text { 3M ESPE Dental Products } \\
\text { St. Paul, } \\
\text { MN } 55144\end{array}$ \\
\hline SDI Super Etch & Etchant Gel & $37 \%$ wt phosphoric acid & 00601 & SDI \\
\hline
\end{tabular}

cleaned, polished using scalars and pumice, and were stored in distilled water until being used. Class II cavities were prepared with a number 836 cylindrical diamond bur (Diatech diamond AG, Swiss). The cavities were prepared following a standardized pattern in which class II cavity had a length of $3.0 \mathrm{~mm}$, width of $2.0 \mathrm{~mm}$, and depth of $2.0 \mathrm{~mm}$ occlusally. The proximal box had an axial depth of $1.5 \mathrm{~mm}$ and buccolingual width of $4.0 \mathrm{~mm}$. The cervical margin of the proximal box was located 1.0 $\mathrm{mm}$ below the CEJ [7]. The specimens were then randomly divided into two experimental groups, with 10 teeth each. All cavities were etched (enamel and dentin) with $37 \%$ phosphoric acid for 15 seconds according to the manufacturer's instructions, rinsed with air/water spray for 20 seconds followed by gentle drying for 5 seconds. Dentin bonding agent was applied to the etched tooth surface. Adper ${ }^{\mathrm{TM}}$ Single Bond 2 Adhesive was applied to group $a_{1}$ and Prime- Dent ${ }^{\circledR}$ was applied group $a_{2}$. The teeth were then restored with Filtek Supreme (group a1) and Prime-Dent ${ }^{\circledR}$ (group a2). The resin-based composites were placed incrementally in three layers, and each layer was cured for 40 seconds from the occlusal direction according to the manufacturer's instructions for cavity class II compound. After the last increment was placed, the matrix band was removed. The restoration was also light-cured for 40 seconds from both the buccal and lingual walls according to the manufacturer's instructions [7].

The restored teeth were stored for 24 hours in distilled water, and thermocycled for 2500 cycles between $5^{\circ} \mathrm{C}$ and $55^{\circ} \mathrm{C}$ with a dwell time of 30 seconds in each bath [8]. The apices of the specimens were sealed with sticky wax, and all tooth surfaces were covered with two coats of clear nail polish with exception of $1.0 \mathrm{~mm}$ around the tooth-restoration margins and allowed to air dry. Specimens were then immersed in $2 \%$ methylene blue dye. The teeth were sectioned along the mesio-distal direction, coincident with the center of the restoration, with a sectioning diamond disc under water spray from chip syringe. The dye penetration of the occlusal and gingival margins of each section was evaluated independently by the observers using a stereo-microscope (Olymbus SZ 60, Japan) at a magnification of X 10 and scored as follow [7]: 0-No dye penetration; 1-Dye penetrations up to but not beyond $1 / 2$ the occlusal or gingival wall; 2 -Dye penetration up to but not contacting the axial wall.

\section{Statistical Analysis}

The data obtained were tabulated for statistical analysis which was conducted using SPSS (Statistical Package for Social Science) version 10. Chi-Square test was used to detect the significant differences among the variables tested.

\section{Results}

The results of microleakage are presented in Tables 2-5. Chi-square test demonstrated no significant difference between the microleakage of nanofilled composite (Filtek Supreme) and hybrid composite (Prime-Dent) restorations at occlusal/enamel margins $(P>0.05)$ (Table 2$)$. At the same time, there were no significant differences at gingival/dentin margins $(P>0.05)$ (Table 3$)$.

There were no significant differences for nanofilled composite restorations at occlusal/enamel margins and gingival/dentin margins $(P>0.05)$ (Table 4). On the other hand, there were a significant differences for hybrid composite restorations at occlusal/enamel margins and gingival/dentin margins $(P \leq 0.01)$ (Table 5).

\section{Discussion}

Microleakage is defined as dynamic clinically undetectable passage of bacteria, fluids, chemical substances, molecules and ions between the cavity walls and the restorative material applied. Microleakage is used as a 
Table 2. Chi-square $\left(x^{2}\right)$ and leakage score values of test materials in occlusal/enamel margins.

\begin{tabular}{|c|c|c|c|c|c|c|}
\hline Materials & & eakage & Score & & Chi-Square $\left(x^{2}\right)$ & $P$-value \\
\hline Scores & 0 & 1 & 2 & 3 & & \\
\hline $\begin{array}{l}\text { Nanofilled composite } \\
\qquad(n=10)\end{array}$ & 5 & 2 & 1 & 2 & 1.62 & 0.65 \\
\hline $\begin{array}{l}\text { Hybrid composite } \\
\qquad(n=10)\end{array}$ & 3 & 2 & 2 & 3 & & \\
\hline
\end{tabular}

Table 3. Chi-square $\left(x^{2}\right)$ and leakage score values of test materials in gingival/dentin margins.

\begin{tabular}{|c|c|c|c|c|c|c|}
\hline Materials & & akage & Scor & & Chi-Square $\left(x^{2}\right)$ & $P$-value \\
\hline Scores & 0 & 1 & 2 & 3 & & \\
\hline $\begin{array}{l}\text { Nanofilled composite } \\
\qquad(n=10)\end{array}$ & 1 & 3 & 1 & 5 & 6.47 & 0.09 \\
\hline $\begin{array}{l}\text { Hybrid composite } \\
\quad(n=10)\end{array}$ & 0 & 1 & 3 & 6 & & \\
\hline
\end{tabular}

Table 4. Chi-square $\left(x^{2}\right)$ and leakage score values of nanofilled composite restorative materials in occlusal/enamel and gingival/dentin margins.

\begin{tabular}{|c|c|c|c|c|c|c|}
\hline Materials & & Leakage & Score & & Chi-Square $\left(x^{2}\right)$ & $P$-value \\
\hline Scores & 0 & 1 & 2 & 3 & & \\
\hline $\begin{array}{l}\text { Nanofilled composite } \\
\qquad(n=10)\end{array}$ & 1 & 3 & 1 & 5 & 6.47 & 0.09 \\
\hline $\begin{array}{l}\text { Hybrid composite } \\
\qquad(n=10)\end{array}$ & 0 & 1 & 3 & 6 & & \\
\hline
\end{tabular}

Table 5. Chi-square $\left(x^{2}\right)$ and leakage score values of hybrid composite restorative materials in occlusal/enamel and gingival/dentin margins.

\begin{tabular}{|c|c|c|c|c|c|c|}
\hline Materials & & Leakage & Score & & Chi-Square $\left(x^{2}\right)$ & $P$-value \\
\hline Scores & 0 & 1 & 2 & 3 & & \\
\hline $\begin{array}{l}\text { Nanofilled composite } \\
\qquad(n=10)\end{array}$ & 3 & 2 & 2 & 3 & 6.47 & 0.09 \\
\hline $\begin{array}{l}\text { Hybrid composite } \\
\qquad(n=10)\end{array}$ & 0 & 1 & 3 & 6 & & \\
\hline
\end{tabular}

measure by which clinicians and researchers can predict the performance of restorative materials in the oral environment $[9,10]$.

Microleakage is caused by polymerization shrinkage of composite restorative materials. High bond strength between the restoration and the dentin surface may resist the polymerization shrinkage of the restoration and subsequent microgap formation at the tooth-restoration in- terface [11]. Poor adaptation of the restorative materials to cavity walls and margins and the method by which the restorative material is inserted may affect the sealing properties of the restorative material $[12,13]$. Difference in coefficient of thermal expansion and contraction between tooth structure and the applied restorative material had been implicated in microleakage through marginal percolation or through disruption of the marginal enamel etch bond, allowing microleakage in the space resulting from thermal contraction [14]. It has also been found that the type of occlusion and masticatory forces have a marked effect on the development of marginal leakage in composite restorations. The frequency of marginal leakage was significantly greater in teeth that were in functional occlusion than in similar teeth without antagonist $[14,15]$. The oral environment is also of importance in determining the extent of marginal leakage, where both restoration and surrounding tooth substance are subjected to mechanical loading and temperature variations when become in contact with food, saliva and microorganisms $[15,16]$.

Modulus of elasticity of the restorative material can also be considered one of the causes of marginal microleakage [17]. Therefore, the importance of applying an intermediary layer with a low elasticity module or a stress breaker layer. This layer would then provide enough flexibility to compensate the tension generated by polymerization shrinkage [18].

In clinical practice, three commonly encountered problems may be associated with microleakage in dental restorations. These problems are postoperative sensitivity [19], marginal percolation [14], secondary marginal caries [19]. The incremental placement technique in the restoration of Class II cavity preparations seems to improve the marginal seal of the proximal walls of finished restorations [20].

In this study dye penetration method was used to evaluate the microleakage because methylene blue dye penetration method provides the evaluators with a perfect and easy visualization of the prepared cavity in the digital images which provide the evaluators with a clear reference point from which to score. The dye also provides an excellent contrast with the surrounding environment [21].

All tested groups showed dye penetration at the tooth-restoration interface. This could be attributed to the dimensional changes of the resin material which often result from polymerization shrinkage of the restorative resin, and differences in coefficient of thermal expansion and contraction between the tooth and the restorative material. These changes in the material produce internal forces that results in gap formation at the tooth-restoration interface, which in turn causes microleakage [22]. 
The results of the present study showed that, the score of microleakage values was lower for nanofilled composite than hybrid composite in all groups, but the difference was not significant. The score of microleakage values was lower for two types of composite restorations at the occlusal margins than at the gingival margins placed below the cemento-enamel junction (CEJ) and the difference was significant for hybrid composite restorations, but was not significant for nanofilled composite restorations. These results could be attributed to the inadequate adaptation of resin composite restoration in posterior teeth caused by the great dentin/enamel proportion in the cervical area and the critical difference of the thermal expansion coefficient between the tooth and the restorative material which allowed tracing agent penetration [23-26].

In this study, gingival/dentin margins showed significantly higher leakage than occlusal/enamel margins in hybrid composite restorative materials. This was expected as the bond strength to enamel is usually higher than bond strength to dentin, as dentin is a less favorable bonding substrate and the heterogeneous structure of dentin also affects the quality of bonding of the current dentine bonding systems [27-31]. Also, the orientation of dentinal tubules can affect the formation of the hybrid layer. In areas with perpendicular tubule orientation, the hybrid layer was significantly thicker than areas with parallel tubule orientation. Therefore, the dentine surface on the gingival floor of class II preparations may be a surface on which good hybrid layer formation is difficult the fact that contributed to the results of the present study in which substantial leakage occurred [32]. In the present study, the absence of statistically significant differences between occlusal and gingival margins could attributed to the high and reliable dentin bond strength of the used adhesives. The gaps between restorative material and cavity walls generally occur when the bonding capacity of the adhesive systems is insufficient to resist the forces of polymerization shrinkage of the composites [33].

Clinically, there were many attempts to reduce microleakage around restorations. During cavity preparation, all surfaces should be smoothed, cleaned dried to achieve maximum adaptation of the restoration to the cavity walls. It has also been found that beveling of cavosurface margins would provide for an increase in marginal surfaces which in turn, would compensate for polymerization shrinkage to some extent [34-36]. Removal of smear layer by acid etching increase the permeability of dentin by exposing the orifices of dentinal tubules [37,38]. Increasing surface area for bonding by means of acid etching technique followed by application of direct adhesive was found to significantly reduce microleakage level [39-41]. Good adhesion of the restorative materials to tooth structure $[9,35,37]$.

\section{Conclusions}

There was no significant difference among the tested materials regarding the microleakage.

\section{REFERENCES}

[1] J. Mahart and R. Hickel, "Esthetic Compomer Restorations in Posterior Teeth Using a New All-in-one Adhesives: Case Presentation," Journal of Esthetic and Restorative Dentistry, Vol. 11, No. 5, 1999, pp. 250-258. doi:10.1111/j.1708-8240.1999.tb00406.x

[2] J. F. Roulet, "The Problems Associated with Substituting Composite Resins for Amalgam: A Status Report on Posterior Composites," Journal of Dentistry, Vol. 16, No. 3 , 1988, pp. 101-103. doi:10.1016/0300-5712(88)90001-2

[3] S. C. Bayne, H. O. Heymann and E. J. Swift, "Update on Dental Composite Restoration," The Journal of the American Dental Association, Vol. 125, No. 6, 1994, pp. 687 701.

[4] N. Attar and M. D. Turgut, "Fluoride Release and Uptake Capacities of Fluoride Releasing Restorative Materials," Operative Dentistry, Vol. 28, No. 4, 2003, pp. 395-402.

[5] J. Mahart, H. Y. Chen and R. Hickel, "The Suitability of Packable Resin-Based Composites for Posterior Restorations," The Journal of the American Dental Association, Vol. 132, No. 5, 2001, pp. 639-645.

[6] K. F. Leinfelder, "Posterior Composite Resins: The Materials and Their Clinical Performance," The Journal of the American Dental Association, Vol. 126, No. 5, 1995, pp. 663-672.

[7] O. Bala, M. B. Üctasli and I. Ünlu, "The Leakage of Class II Cavities Restored with Packable Resin-Based Composites," Journal of Contemporary Dental Practice, Vol. 4, No. 4, 2003, pp. 1-11.

[8] D. Simone, N. B. David, P. Aikaterini and P. Ronald, "Microleakage of Resin-Based Liner Materials and ConDensable Composites Using Filled and Unfilled Adhesives," American Journal of Dentistry, Vol. 16, No. 5, 2003, pp. 351-355.

[9] J. G. Bauer and J. L. Henson, "Microleakage. A Measure of the Performance of Direct Filling Materials," Operative Dentistry, Vol. 9, No. 1, 1984, pp. 2-9.

[10] B. Torsten, M. Brannstrom and B. Maltson, "A New Method for Sealing Composite Resin Contraction Gaps in Lined Cavities," Journal of Dental Research, Vol. 64, No. 3, 1985, pp. 450-453. doi:10.1177/00220345850640031201

[11] J. D. Eick and F. H. Welch, "Polymerization of Posterior Composite Resins and Its Possible Influences on Postoperative Sensitivity," Quintessence International, Vol. 17, No. 2, 1986, pp. 103-111.

[12] D. Fortin, E. J. Swift, G. E. Denehy and J. W. Reinhardt, "Bond Strength and Microleakage of Current Dentin Adhesives," Dental Materials, Vol. 10, No. 4, 1994, pp. 253- 


\section{8. doi:10.1016/0109-5641(94)90070-1}

[13] J. R. Holtan, G. P. Nystrom, S. E. Rensen, R. A. Phelps and W. H. Douglas, "Microleakage of Five Dental Adhesives," Operative Dentistry, Vol. 19, No. 2, 1993, pp. 189-193.

[14] V. Quist, "The Effect of Mastication on Marginal Adaptation of Composite Restorations in vivo," Journal of Dental Research, Vol. 72, No. 1, 1993, pp. 490-494.

[15] D. B. Mohler and L. W. Nelson, "Factors Affecting on the Marginal Leakage of Amalgam," The Journal of the American Dental Association, Vol. 108, No. 1, 1984, pp. 51-54.

[16] M. Brannstrom, "Communication between the Oral Cavity and the Dental Pulp Associated with Restorative Treat- ment," Operative Dentistry, Vol. 9, No. 2, 1984, pp. 57-66.

[17] D. H. Retief, "Do Adhesive Prevent Microleakage?" International Dental Journal, Vol. 44, No. 1, 1994, pp. 19-26.

[18] T. C. Steet, J. Perdigão and E. J. Swift, "Marginal Adaptation of Composite Restorations with and without Flowable Liner," Journal of Dental Research, Vol. 79, No. 2, 2001, pp. 269-275.

[19] M. Brannstrom and K. J. Nordenvall, "Bacterial Penetration, Pulp Reaction and Inner Surface of Concise Enamel Bond Composite Fillings in Etched and un Etched Cavities," Journal of Dental Research, Vol. 57, No. 1, 1978, pp. 3-10. doi:10.1177/00220345780570011301

[20] K. W. Fouad and J. S. H. Firas, "Evaluation of the MicroLeakage at the Proximal Walls of Class II Cavities Restored Using Resin Composite and Procured Composite Inserts," Quintessence International, Vol. 34, 2003, pp. 600-606.

[21] J. B. Almeida, J. A. Platt, Y. Oshida, B. K. Moore, M. A. Cochran and G. J. Eckert, "Three Different Methods to Evaluate Microleakage of Packable Composites in Class II Restorations," Operative Dentistry, Vol. 28, No. 4 , 2003, pp. 453-460.

[22] E. Elias and G. Sajjan, "Effect of Bleaching on MicroLeakage of Resin Composite Restorations in Non-Vital Teeth. An in-vitro Study," Journal of Endodontics, Vol. 14, 2002, pp. 9-13.

[23] W. W. Barkmeier and A. L. Cooley, "Laboratory Evaluation of Adhesive System," Operative Dentistry, Vol. 17, Suppl 5, 1992, pp. 50-61.

[24] J. Kanca, "Posterior Composite Microleakage Below the Cementoenamel Junction," Operative Dentistry, Vol. 18, No. 5, 1987, pp. 347-349.

[25] N. Nakabayashi, K. Kojima and E. Masuhara, "The Promotion of Adhesion by Infiltration of Monomers into Tooth Substrates," Journal of Biomedical Materials Research, Vol. 16, No. 3, 1982, pp. 265-273. doi:10.1002/jbm.820160307

[26] R. R. Russel and R. B. Mazer, "Should Flowable Composites be Used as Liners for Class II Restorations?" Journal of Dental Research, Vol. 78, No. 3, 1999, pp.
389-392.

[27] W. S. Eakle and R. K. Ito, "Effect of Insertion Technique on Microleakage in Mesio-Occlusodistal Composite Resin Restorations," Quintessence International, Vol. 21, No. 5, 1990, pp. 369-374.

[28] T. J. Hilton, R. S. Schwartzs and J. L. Ferracane, "Microleakage of Four Class II Resin Composite Insertion Techniques at Intraoral Temperature," Quintessence International, Vol. 28, No. 2, 1997, pp. 135-144.

[29] C. Leevailoj, M. A. Cochran, B. A. Martis, B. K. Moore and J. Platt, "Microleakage of Posterior Packable Resin Composites with and without Flowable Liners," Operative Dentistry, Vol. 26, No. 3, 2001, pp. 302-307.

[30] L. A. Linden, O. Kallskog and M. Wolgast, "Human Dentin as a Hydrogel," Archives of Oral Biology, Vol. 40, No. 11, 1996, pp. 991-1004. doi:10.1016/0003-9969(95)00078-4

[31] A. L. Neme, B. B. Maxson and F. E. Pink, "Microleakage of Class II Packable Resin Composites Lined with Flowables: An in vitro Study," Operative Dentistry, Vol. 27, No. 6, 2002, pp. 600-605.

[32] M. Ogata, M. Okuda and M. Nakajima, "Influence of the Direction of Tubules on Bond Strength to Dentin," Operative Dentistry, Vol. 26, 2001, pp. 27-35.

[33] C. Parti, L. Tao, M. Simpson and D. H. Pashley, "Permeability and Microleakage of Class II Resin Composite Restorations," Journal of Dentistry, Vol. 22, No. 1, 1994, pp. 49-56.

[34] A. Ben-Amar and H. S. Cardash, "The Fluid-Filled Gap under Amalgam and Resin Composite Restorations," American Journal of Dentistry, Vol. 4, No. 5, 1991, pp. 226-230.

[35] F. Lutz, T. Imfeld, F. Barbakow and W. Iselin, "Optimizing the Marginal Adaptation of MOD Composite Restorations. In: G. Vanherle and D. C. Smith, Eds., Posterior Composite Resin Dental Restorative Materials, Peter Szulc Publishing Co., Netherlands, 1985, pp. 405-419.

[36] M. Staninec, A. Mochizuki and K. Fuckuda, "Interfacial space, Marginal Leakage and Enamel Cracks around Composite Resins," Operative Dentistry, Vol. 11, No. 1, 1986, pp. 14-24.

[37] R. L. Bowen, K. R. Nemoto and J. E. Rapson, “Adhesive Bonding of Various Material to Hard Tooth Tissue Force Developed in Composite Materials during Hardening," The Journal of the American Dental Association, Vol. 106, No. 4, 1983, pp. 475-477.

[38] M. G. Buonocore, "A Simple Method of Increasing the Adhesion of Acrylic Filling Materials to Enamel Surface," Journal of Dental Research, Vol. 34, No. 6, 1955, pp. 849-853. doi:10.1177/00220345550340060801

[39] M. Brannstrom and H. Nyborg, "Cavity Treatment with a Microbiocidal Fluoride Solution: Growth of Bacteria and Effect on Pulp," The Journal of Prosthetic Dentistry, Vol. 30, No. 3, 1973, pp. 303-310. doi:10.1016/0022-3913(73)90187-X

[40] S. P. Gray and B. D. Chewing, "Reducing Marginal Lea- 
kage in Posterior Composite Resin Restorations. A Review of Clinical Technique," The Journal of Prosthetic Dentistry, Vol. 63, No. 3, 1990, pp. 286-288.

[41] D. H. Pashley, V. Michelich and T. Kehl, "Dentin Per-
Meability Effect of Smear Layer Removal," The Journal of Prosthetic Dentistry, Vol. 46, No. 5, 1981, pp. 531-537. doi:10.1016/0022-3913(81)90243-2 